\title{
Ecological Sanitation in Tropical Environments: Quantifying the Inactivation Rates of Microbiological Parameters During a Feces-Based Composting Process
}

\author{
Effebi Kokoh Rose, PhD \\ Ouattara Issouf, MSc
}

Unité de Formation et de Recherche en Sciences et Gestion de l'Environnement (UFR-SGE), Laboratoire de Geosciences et Environnement

Université Nangui Abrogoua, Abidjan, Côte d'Ivoire

Ouattara Koffi Nouho, PhD

Unité de Formation et de Recherche en Sciences et Gestion de

l'Environnement (UFR-SGE), Laboratoire Environnement et Biologie

aquatique, Université Nangui Abrogoua, Abidjan, Côte d'Ivoire

Kouadio Louis, PhD

International Centre of Applied Climate Sciences,

University of Southern Queensland, Toowoomba, Australia

Doi: 10.19044/esj.2017.v13n29p290 URL:http://dx.doi.org/10.19044/esj.2017.v13n29p290

\section{Abstract}

Dry composting toilets are increasingly being used as practical sanitation systems in areas with inadequate sewage disposal and inefficient (or inexistent) hydraulic network. In Côte d'Ivoire, the by-products from such systems are progressively used in peri-urban agriculture as organic fertilizer, most of the times regardless of any hygienic quality assessment; constituting thereby a major health risk. The main objective of this study was to assess the inactivation rates of key microbiological parameters [i.e., total coliforms (TC), fecal coliforms (FC), fecal streptococci (FS) and Ascaris lumbricoides (AL)] during the composting process of fecal matters from dry composting toilets. Feces from dry composting toilets pits located at AboboSabgé, Abidjan, Côte d'Ivoire, were collected every two weeks from February to June 2017 and their microbiological contents, along with two physico-chemical characteristics (moisture content and $\mathrm{pH}$ ) were analyzed. Results revealed noticeable concentration decreases for all the microbiological parameters, except AL. The concentrations dropped from 7.72 to $3.93,7.61$ to 2.70 , and 7.10 to $3.11(\log \mathrm{FCU} / \mathrm{g})$ for TC, FC and FS, respectively, during the monitoring period. Regarding $\mathrm{AL}$, there was an 
increase during the first 29 days, then a decrease in their concentrations over the last 3 months. Furthermore, the study revealed that all fecal bacteria followed a first-order kinetic with the inactivation rates being $0.31,0.24$, and $0.21 \mathrm{~d}^{-1}$ for FC, TC and FS, respectively. The amount of fecal bacteria in the composts suggests that an additional time is required for maturation before any uses of such material as fertilizer.

Keywords: Compost, Dry composting toilets, Ecological sanitation, Kinetic, Microorganisms, Sub-Saharan country

\section{Introduction}

Managing wastewater and solid waste is one of the major challenges faced by governments and other decision makers in terms of public health safety in developing countries. Given the lack of collective purification plants such as activated sludge types, fixed-bed reactors, and lagoon ponds, non-collective sanitation (e.g., pit septic toilets, rudimentary latrines, public toilets, etc.) are increasingly being used in those areas (Pambrun, 2005). However, serious flaws occur in their management when it comes to handling the solid wastes generated. For example, solid wastes are often disposed in gutters, rivers, or public squares, favoring subsequently the development of water-borne diseases such as dysentery, typhoid fever, cholera, diarrhea, intestinal infections, hookworm infection, schistosomiasis or bilharzia, all well-known as the main causes of general mortality and infant morbidity in tropical African countries (Franceys et al., 1995; Cofie et al., 2006). The failing disposal of such materials can also lead to serious environmental risks (e.g., odors, ground and surface water pollution, destruction of urban aesthetics, eutrophication, etc.) over the short or long term. A better management of these solid wastes is therefore required to ensure an environmentally friendly sanitation and avoid (or reduce) any public health risks. One management option could be to provide such solid wastes with an additional added value through their composting. This could also enable actors in this sector ensure their financial autonomy while promoting a sustainable ecological sanitation (Nsavyimana, 2014).

Among the existing non-collective sanitation systems, dry composting toilets with urine deflection are less expensive and do not require high technology compared to conventional systems (Magri et al. 2013). Moreover, this ecological sanitation system has the potential to upgrade urine and feces through their use as fertilizers, which thus become resources rather than wastes (Ogunyoku et al. 2016). Dry composting toilets are also accessible to all, less fragrant, more practical and quick to build, more durable and profitable, while providing better protection of the water table. 
Other advantages include ease of maintenance, reasonable investment cost, and sources of additional incomes (Diabagaté, 2009).

All biological processes as well as reaction rate can be influenced by several factors during composting. Moisture content and temperature are among those factors which should be controlled and monitored carefully during composting (Aya et al. 2015). Feces-based composts may contain key plants nutrients as well as different types of microorganisms (sometimes pathogenic). During the composting process, it is assumed that pathogens present in feces are inactivated given the elevated temperatures that can be reached (about $55-65^{\circ} \mathrm{C}$ at the third step of composting) (Sossou et al. 2016). However, when the process is not well carried out, the final compost may contain pathogenic microorganisms. Therefore, before any reuse as fertilizer or soil conditioner, this final compost should be disinfected. To control the destruction of all pathogenic microorganisms, fecal bacteria are used as indicator to determine the inactivation rate of fecal microorganisms in the compost product (Darimani et al. 2016). However, all the processes involving in feces-based composting for obtaining stable and harmless composts have yet to be well documented. Reported studies are generally limited to the description of the functions of the dry composting toilets and their advantages. Only a few deal with the sanitary and hygienic aspects of composts. The main objective of this study is therefore to assess the inactivation rates of key microbiological parameters such as total coliforms (TC), fecal coliforms (FC), fecal streptococci (FS), and Ascaris lumbricoides (AL) during a composting process of fecal matters from dry composting toilets located in a rapidly urbanizing city in a Sub-Saharan country (i.e. Côte d'Ivoire). These microbiological parameters are essential for determining the stability and ensuring further safe and hygienic use of the compost.

\section{Material and Methods \\ Study area}

The study area was Abobo-Sagbé, one of the south-western neighborhoods of Abobo. Located in the North of Abidjan, the municipality of Abobo is one of the thirteen (13) municipalities of the Autonomous District of Abidjan. Its population is estimated at circa 1.5 million inhabitants (RGPH, 2014), for an area of approximately 9,000 ha. Abobo has long played the role of refuge for economically vulnerable populations who are unable to afford rental housing in all buildings. This has favored the creation of large urban fringes which do not obey any sustainable urban plan (Kouassi, 2008). Twenty-eight (28) neighborhoods and villages make up the municipality of Abobo, including a dozen precarious neighborhoods where $60 \%$ of its population live (ONU-Habitat, 2012). Abobo-Sagbé covers an 
area of 430 ha, with a population of circa 100,000 inhabitants. The average annual growth rate is 3\% (INS, 2001).

The study was part of a project aiming at (i) offering dry composting toilets to people in urban slums such as Abobo-Sagbé in order to stop openair defecations, and (ii) generating new job opportunities while ensuring the management of excreta in households and the healthy use of dry composting toilets by-product as fertilizer in agriculture. The filling time of the receptacles of materials was highly dependent on users.

\section{Data collection}

In our study one pit of dry composting toilet (total volume $=1 \mathrm{~m}^{3}$ ), used by approximatively 25 individuals, was monitored for 5.5 months. A dry composting toilet is based on the principle of separation between urine and feces. Fecal matters were collected directly in a pit mounted above ground (the urine being channeled via a PVC and collected in a receptacle located outside the latrine) (Figure 1). They were then treated in two phases. The first phase was a desiccation which occurred simultaneously during collection in a ventilated pit and consisted to the addition of a bulking agent (e.g., sawdust or chips) after each defecation. This helps absorbing moisture, and reducing the risk of odor and proliferation of flies. The second phase (also called dehydration) begun after the filling of the receptacle and its closure for the composting process.

The collection of feces-based compost samples was conducted over 133 days of composting, starting on February 7, 2017. The depth of the compost pit was $1 \mathrm{~m}$. The sampling was performed at three vertical positions in the compost pit: at the top (0-5 cm from top), mid-depth $(45-55 \mathrm{~cm}$ from top) and depth (90 cm from top), (Figure 2). They were then carefully mixed as one content and 1-kg sample was collected and stored in sterile plastic bags for the determination of the physico-chemical (moisture content and $\mathrm{pH}$ ) and microbiological (TC, FC, FS, and AL) characteristics in laboratory. The $\mathrm{pH}$ values of the samples were also determined in situ. Then, the sample was transported to the laboratory in an ice chest on the same day (within 2 hours after collection). 

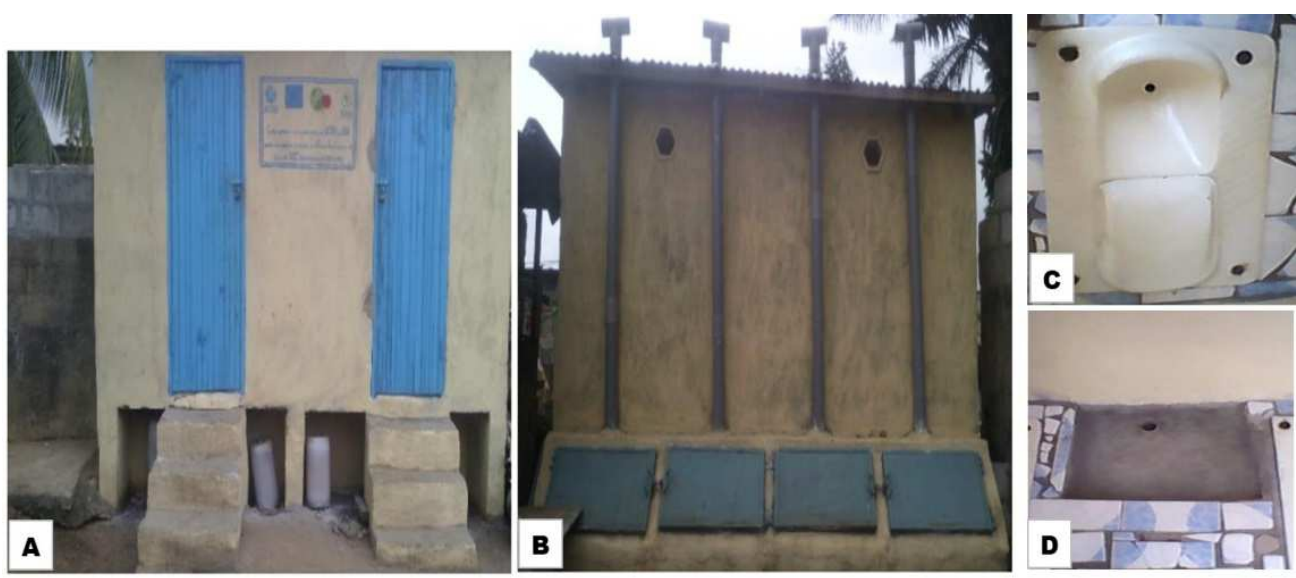

Figure 1. Dry composting toilets monitored in the experiment. A. Front view; B. Rear view; C. Orifice for urine collection and valve covering the pit; D. Wastewater collecting orifice (wastewaters are from hand and anal washing water after each defecation).

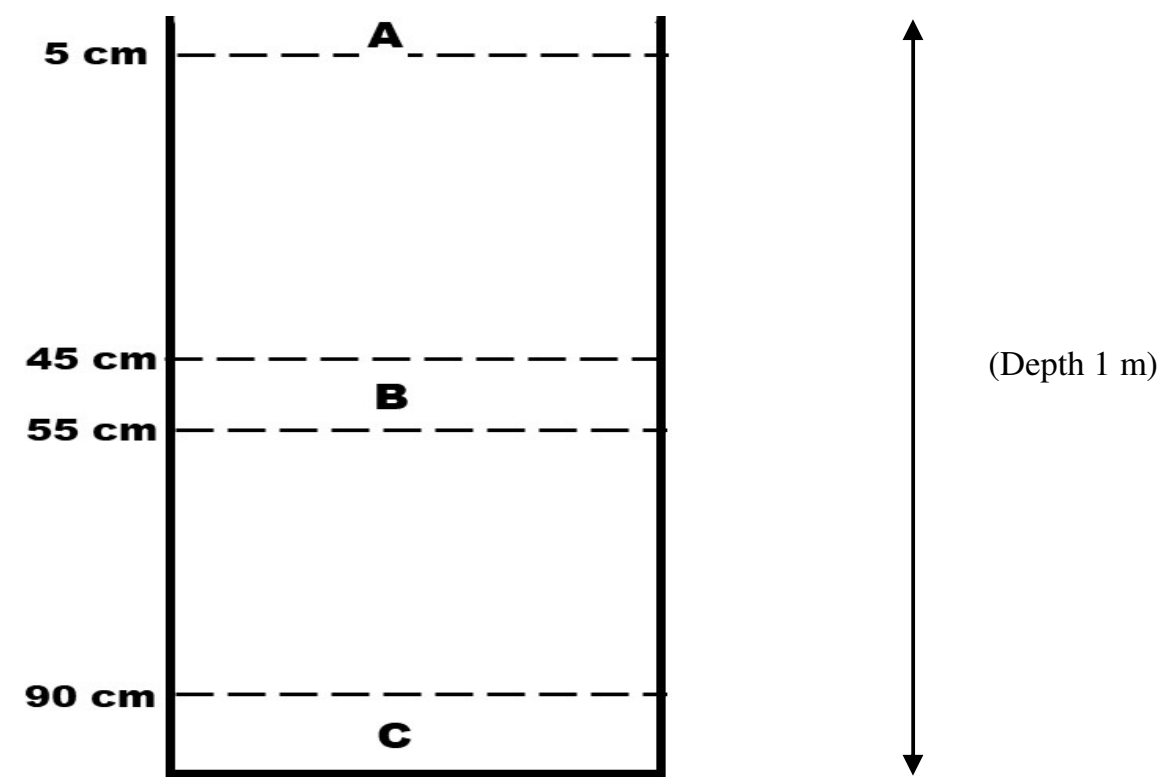

Figure 2. Schematic pit profile and sampling depths: top (A), mid-depth (B) and bottom (C)

\section{Laboratory analyses}

The $\mathrm{pH}$ was determined according to NF T 90-006 (1950). $20 \mathrm{mg}$ of feces-based compost were dissolved in $100 \mathrm{~mL}$ of distilled water. The whole was stirred for 5 minutes at room temperature with a mechanical stirrer. After settling, measurements were made on the liquid portion only using a multi-parametric probe HACH HQ 4O D.

Regarding the determination of the moisture content, the proportion of dry matter (DM) was first determined. $10 \mathrm{~g}$ of compost was sampled and 
put in an aluminum container. It was then dried in an oven at $105^{\circ} \mathrm{C}$ and cooled in a desiccator. DM was calculated as follows:

$$
D M=\frac{A \times 100}{B}
$$

where $D M$ is expressed in percentage (\%); $A$ and $B$ refer to the mass of the sample (g) after and before drying $(\mathrm{g})$.

The moisture content was then deducted as:

$$
\% \text { moisture }=100-\% \mathrm{DM}
$$

The method used for detecting pathogenic bacteria was based on membrane filtration (NF, 2000). $20 \mathrm{mg}$ were sampled and dissolved in 100 $\mathrm{mL}$ of distilled water. After stirring and settling, $1 \mathrm{~mL}$ was sampled and filtered through sterile filter membrane $(0.45 \mu \mathrm{m}$ in diameter $)$. After filtration, the membrane was placed under sterile conditions on petri dishes containing a solid culture medium (agar) before being incubated for 30 minutes at precise temperatures permitting the identification of the bacteria. For seeding, the culture media used varied according to the bacteria sought (i.e., "COMPASS $®$ cc" and "Slanetz and Bartley" agars for FC and FS, respectively). The determination of $\mathrm{FC}$ was carried out after 18 to 24 hours of incubation at $44^{\circ} \mathrm{C}$. FC colonies appear in blue. As for FS, their determination was performed after $44 \pm 4$ hours of incubation at $37^{\circ} \mathrm{C}$. FC colonies appear in dark roses or reds with or without a white aureole. Total coliforms included all the present colonies in the culture media (that is, FS + FC). They corresponded to the bacterial load of the seeded inoculum.

Considering the dilution rates of the samples, the number of bacteria was calculated as follows:

$$
C_{S}=\frac{N \times V_{S}}{n_{1} v_{1} d_{1}+n_{2} v_{2} d_{2}}
$$

where $C s$ (expressed in Forming Colonies Unit, FCU) is the number of bacteria in the reference volume chosen to express the bacterial load $V s ; d_{l}$ and $d_{2}$ are the dilutions used for the test volumes $v_{1}, v_{2}$, respectively; $n_{1}$ and $n_{2}$ are the number of boxes counted for dilutions $d_{l}$ and $d_{2}$; and $N$ is the sum of all colonies counted in the dishes after dilutions.

The number of Ascaris lumbricoides eggs were determined using a method involving sodium acetate-acetic acid-formaldehyde (SAF), (Yang et Scholten, 1977). $1 \mathrm{~g}$ of feces-based compost was sampled and dissolved into $100 \mathrm{ml}$ of distilled water. A mixture of $5 \mathrm{ml}$ of sodium acetate $+5 \mathrm{ml}$ of acetic acid was then added to destroy any vegetative forms. Then, two drops of formalin were added to concentrate the eggs. These formal solutions were filtered through a filter membrane and the eggs were collected. AL eggs were then identified based on their aspects and by using a microscope $(10 \times$ 40), and then counted.

Each of the chemical and microbiological analyses was repeated four times. 


\section{Determination of the kinetic rates of inactivation of fecal bacteria}

The determination of the kinetic rates of inactivation of the selected bacteria was done according to John (2002) and Qian et al. (2015). The kinetic was expressed as a first order decay:

$$
\mathrm{C}_{\mathrm{t}}=\mathrm{C}_{\mathrm{o}} \times \mathrm{e}^{(-\mathrm{kt})}
$$

where $C_{t}$ (colonies per grams) refers to the bacteria density at the elapsed time $t(\mathrm{~h}) ; C_{o}$ (colonies per grams) is the initial bacteria density in colonies per grams; and $k\left(\mathrm{~h}^{-1}\right)$ is the decay constant. The linear phase which is more characteristic of decay process was used to calculate the decay rate.

\section{Statistical analysis}

All the mean values of each of the microbiological parameters were compared using a t-test $(\alpha=0.05)$ to check for the statistical significance of their difference. Data analysis was performed using software R version 3.3.2 (Team, 2016). Prior to the comparison, normality tests (i.e., Shapiro test) were performed for each parameter. Whenever the normality test indicated a probability $\mathrm{p}<0.05$ a non-parametric test (i.e. Mann-Whitney) was used (a parametric test being used for $\mathrm{p}>0.05$ ). Thus, the Mann-Whitney was performed for values of FC, TC and FS; while the t-test was used for AL.

\section{Results and Discussion pH values of the feces-based compost}

In our study, the compost $\mathrm{pH}$ decreased from 7.82 to 6.75 during the first 29 days, then increased from 6.75 to 8.19 over the 20 following days, before a $\sim 26 \%$ decrease during the last 3 months (Figure 3 ). There was a statistically significant difference between the $\mathrm{pH}$ values during the composting process $(P=0.0132)$. The $\mathrm{pH}$ is a good indicator of the progress of composting sludge from sewage treatment plants or domestic waste (Jimenez and Garcia, 1991). The slight decrease of $\mathrm{pH}$ at the beginning of the composting process can be explained by the production of organic acids subsequent to the degradation of carbohydrates, lipids and other substances (Mustin, 1987). Moreover, the production of $\mathrm{CO}_{2}$ during aerobic degradation contributes to the acidification of the medium by its dissolution in water and production of carbonic acid.

While studying the effect of biological compost juices on plant diseases, Znaïdi (2002) reported that the compost initially had a pH ranging from 8 to 8.2. In our case basic composts were found after the first month and up to the second month of the monitoring. Such basic environment favors the development of actinomycetes and alkaline bacteria (Mustin, 1987). Jimenez and Garcia (1991) reported a gradual increase in $\mathrm{pH}$ from 7 to 8 during a composting process of urban refuse and urban refuse + sewage sludge. However, Sundberg et al. (2004) showed that in organic household 
waste initial $\mathrm{pH}$ values ranged from 4.5 to 6 . Nevertheless, they pointed out that in a complete and successful process of composting bio-waste the $\mathrm{pH}$ increases to reach 8-9. Such an increase can be explained by the disappearance of fatty acids (Reveille et al., 2003). Cayuela et al. (2006) also observed a similar increase in $\mathrm{pH}$ (7-9) during the composting of waste from the olive industry. Olive wastes contain a substantial proportion of lipids and free organic acids (Cayuela et al., 2006). Tang et al. (2004) hypothesized that the $\mathrm{NH}_{4}{ }^{+}$ions released during the process would also contribute to the $\mathrm{pH}$ increase (although a decreasing trend was observed later during the composting process). The presence of organic acids with short chains mainly acetic and lactic acid could also lead to such acid environment (Beck-Friis et al., 2001). The slight acidification at the beginning of the composting process is noteworthy because this phenomenon is assimilated to an acid production due to incomplete oxidation, a sign of poor oxygenation as highlighted by Francou (2003) and Sundberg et al. (2004).

Acid environments are characteristics of immature composts, whereas the $\mathrm{pH}$ of mature composts ranged from 7 to 9 (Forster et al., 1993). Given a $\mathrm{pH}$ of $\sim 6$ at the end of the monitoring period in our study, the fecesbased compost was not completely mature. Additional time would probably bring it to maturity.

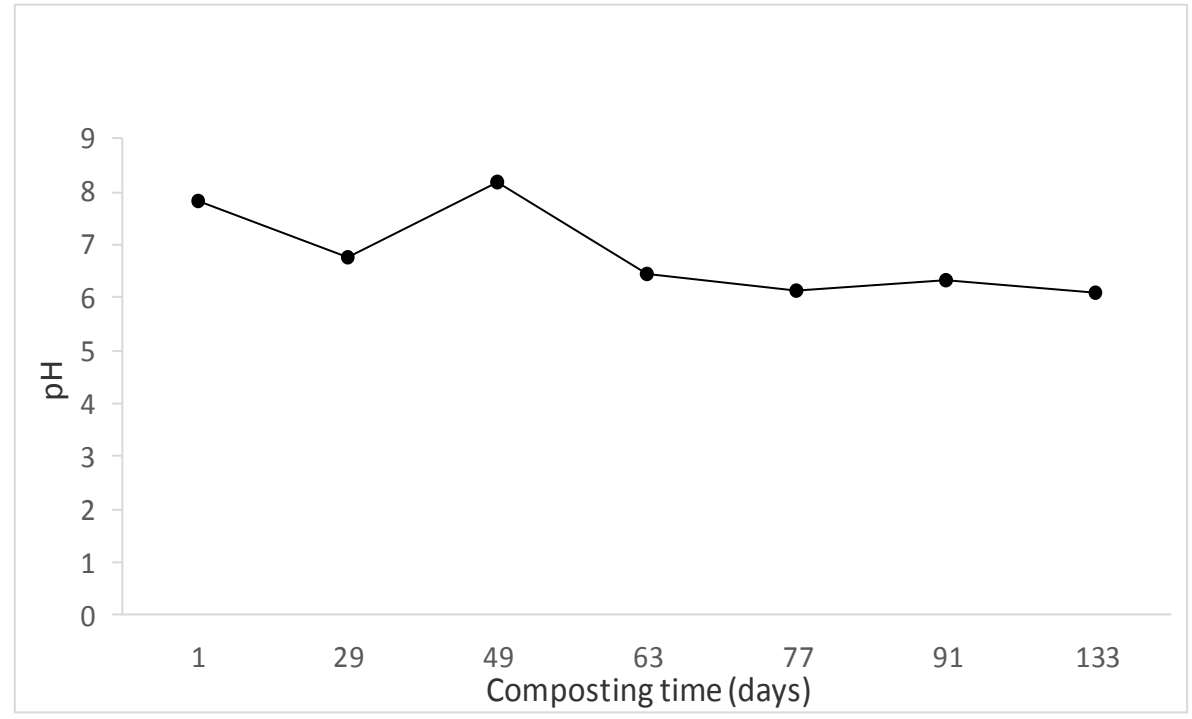

Figure 3. Evolution of $\mathrm{pH}$ during the feces-based composting process

\section{Moisture content in the feces-based compost}

The moisture content remained high (76.6-81.2\%) during the first month of the composting process; then it decreased, down to $69.5 \%$ at the end of the monitoring period (Figure 4). The difference in moisture content was not statistically significant after 133 days of composting $(P=0.4947)$. 
The study area was not sunny during the composting period with an ambient temperature estimated at $26^{\circ} \mathrm{C}$, and generally cloudy. This similarity could be explained by the ambient relative humidity in the study area (Babaammi, 2014). Indeed, while characterizing the microbial biomass developed in a compost from date palm (Phoenix dactylifera) wastes, the piles lose water by evaporation and decreased in volume under the effect of heat and ventilation. The decrease of moisture content in our study was in line with previous studies. Remy (2007) noted a decrease from 55 to $30 \%$ after 180 days during a composting process of municipal solid wastes mixed to green wastes. Canet and Pomares (1995) measured moisture content drops from 60 to 21\% during 90 days of composting of municipal solid wastes. The heat energy released during the composting process is responsible of the evaporation that occurs. The moisture content $(69.5 \%)$ at the end of the 133 days of composting was in line with one of the conclusions reported by Sghairoun (2011) (moisture content $=50-70 \%)$. However, it was too high compared to most recommended material moisture contents (45-50\%) for optimal composting. Although this was not the case in our study, it would be interesting to control this factor by investigating an optimal ratio of bulking agent to feces (e.g., w/w).

Optimum moisture values depend on the nature of the substrate used in composting as well as climatic conditions (Pereira et al., 1987). Low moisture contents $(<25 \%)$ lead to a decrease of biological activities, thereby slowing down the composting process (Laos et al., 2002). On the other hand, for high moisture contents, water saturation can occur, which could stifle the micro-organisms in the composting pile (Leclerc, 1997).

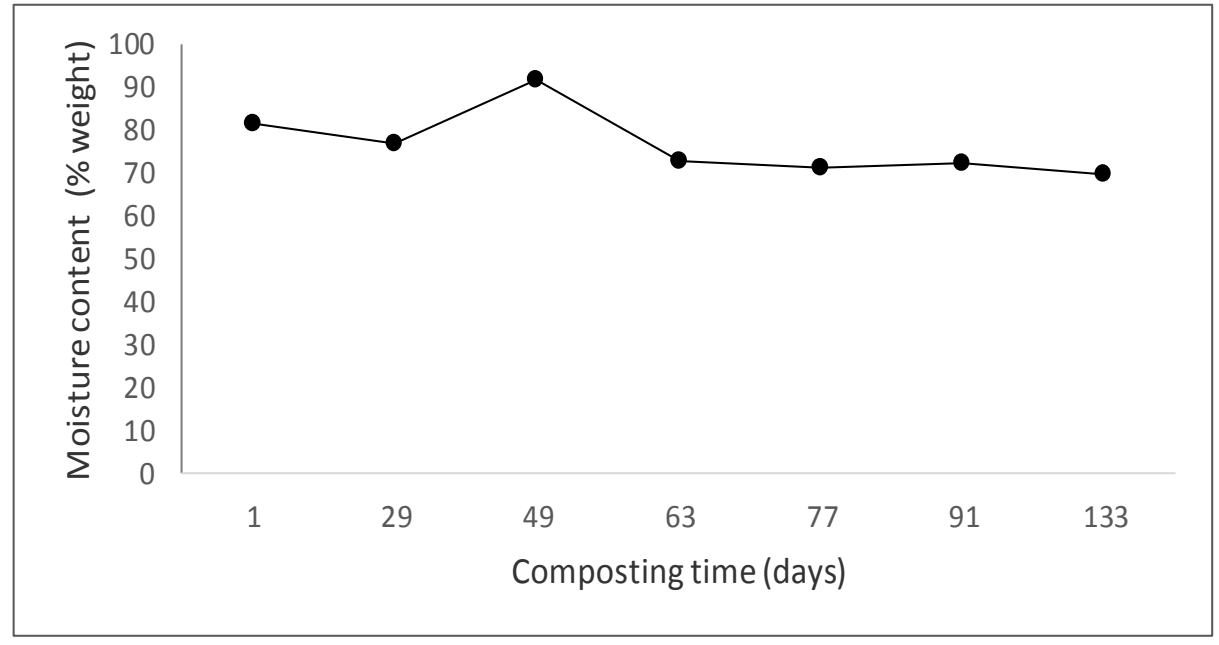

Figure 4. Evolution of the moisture content during the feces-based composting process 


\section{Microbiological parameters in the feces-based compost}

Although a rise in temperature was observed during the first days of composting, namely because of intense biodegradation activities, there was a relatively stable temperature in the compost (on average $25^{\circ} \mathrm{C}$ ) during the composting process (Millner et al., 1977). Such a stabilization of the temperature reflects the end of the intensive degradation phase (Haruta et al., 2005). According to Strom, (1989), temperatures ranging between 60 to $80^{\circ} \mathrm{C}$ are often obtained in the first week of composting, leaving room for thermophilic bacteria. But when the temperature drops again after a few days, the surviving mesophilic microorganisms may readily resume their activity and overcome that of the thermophilic ones. The surviving of those mesophilic bacteria could be explained to their thermo-tolerance or the presence of spores which resumed the life cycle when the conditions were favorable.

There were noticeable decreases of TC, FC and FS concentrations during the first 29 days in the feces-based compost, followed by a relatively low decrease during the last 3.5 months (Figure 5). These three fecal bacteria exhibited biphasic decay patterns, i.e., one linear and one stationary phases. According to previous studies of Nakagawa et al. (2006) and Otaki et al. (2007), the inactivation of microorganisms followed a first order reaction. This is confirmed by our work with a first-order kinetic of inactivation rates being $0.31,0.24$ and $0.21 \mathrm{~d}^{-1}$ for FC, TC, and FS, respectively. Our results are consistent with the findings of Qdais et Al-Widyan (2016) and Sossou (2016) who reported similar kinetic rates using composting and cocomposting piles of several agro-industrial wastes and fecal matter from composting toilets respectively. Regarding $\mathrm{AL}$ an increase was recorded during the first 49 days, before a marked decrease during the last 3 months. The comparison of means showed a statistically significant difference for the different bacterial populations during the study period $(P=0.0005$ in the case of TC, FC and FS; $P=0.0331$ for AL). There was no Ascaris lumbricoides on the first day of composting. According to Damien, 2004, A. lumbricoides constitute the macro-fauna of the compost and generally intervene during the last phase of the process (i.e., maturation) when temperatures are $<40^{\circ} \mathrm{C}$. Helminthes are of special consideration, especially the eggs of Ascaris lumbricoides, because A. lumbricoides eggs are very persistent and not easily inactivate (Feachem et al., 1983; US EPA, 2009).

The composting appears as an effective technique for killing pathogenic microorganisms as long as an appropriate temperature is reached and maintained for sufficient time during the process (Epstein, 1989). Several factors including temperature, death or inhibition of microorganisms caused by the secretion of toxic substances by other microbial strains, and competition for nutrients between microorganisms (either pathogens or not) 
can reduce the bacterial load during the composting process, and more particularly the load of non-pathogen bacteria (Pederson, 1983). Cooper et al. (1977) denoted that actinomycetes and other microscopic fungi present in the organic matter to be composted release antibiotic substances, which are in most cases to most microorganisms.

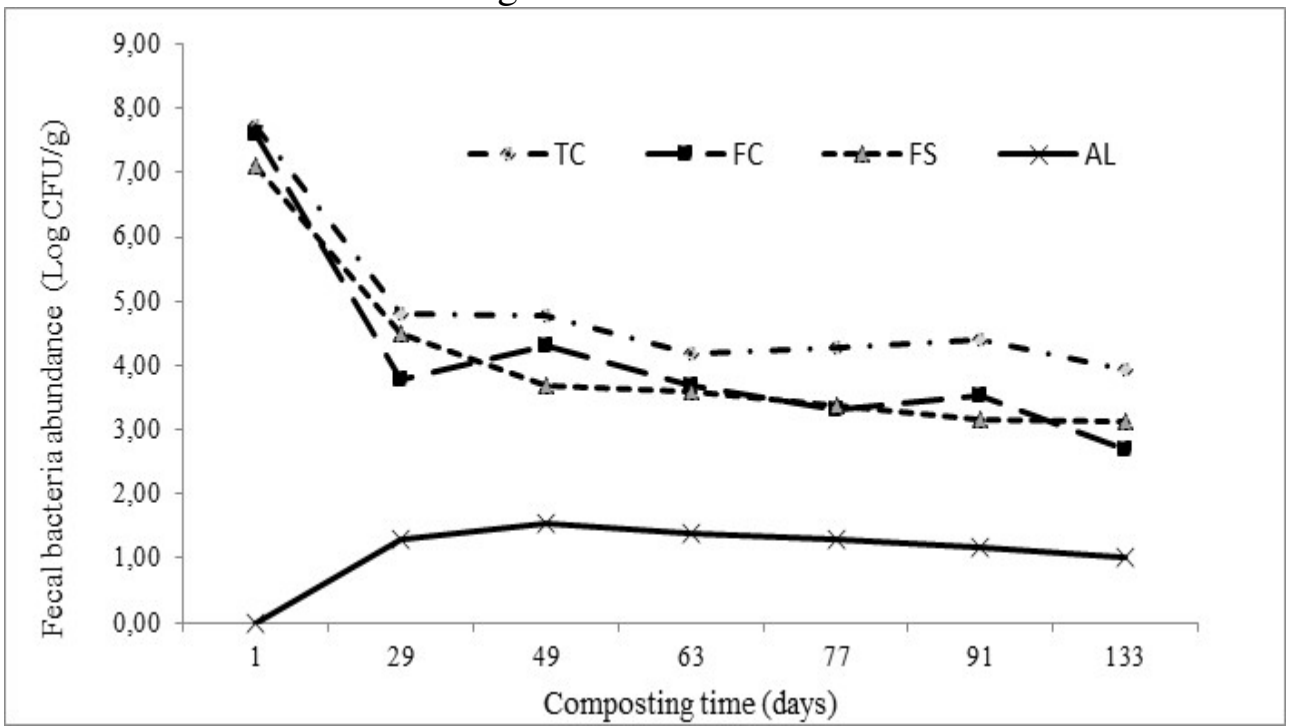

Figure 5. Inactivation kinetics of different fecal contamination germs [i.e., total coliforms (TC), fecal Streptococcus (FS), and fecal coliforms (FC) Ascaris lumbricoides (AL)] during the feces-based composting process.

\section{Conclusion}

We monitored the inactivation kinetics and quantified the inactivation rates of four microbiological parameters (total coliform, fecal coliform, fecal Streptococci, and Ascaris lumbricoides) during a composting process of fecal matters from dry composting toilets in one highly dense urban slum of Abidjan, Côte d'Ivoire. Our findings showed noticeable decreases of TC, FC, and FS contents during the monitoring period, and a lower content of Ascaris lumbricoides at the end of the composting, compared to the other microorganisms. Given the relatively high content of selected microorganisms and the acid nature of the feces-based compost $(\mathrm{pH}=6.08)$ at the end of the monitoring period, the compost was not mature yet. However, the trend observed in the kinetics of microorganisms indicates that the compost was maturing and should be free of harmful fecal bacteria (i.e., reasonable concentrations according to official standards) and suitable for its use for agricultural purposes. 


\section{Acknowledgements}

The authors would like to thank the laboratory personnel of the Ivoirian Anti-Pollution Center (CIAPOL) for their technical assistance.

\section{References:}

1. Aya, E. Z., Hamdy, S., Essam, G. 2015. Moisture content and thermal balance during composting of fish, banana mulch \& municipal solid wastes European Scientific Journal, vol.11, No.5, 19 p.

2. Babaammi, A. 2014. Caractérisation de la biomasse microbienne développée dans un compost issu des déchets du palmier dattier. Mémoire de Master, Universite Kasdi Merbah Ouargla, 61p.

3. Beck-Friis, B., Smars, S., Jonsson, H., \& Kirchmann, H. 2001. SE-Structures and Environment: Gaseous Emissions of Carbon Dioxide, Ammonia and Nitrous Oxide from Organic Household Waste in a Compost Reactor under Different Temperature Regimes. Journal of Agricultural Engineering Research, vol. 78, no 3, 423-430p.

4. Canet, R., \& Pomares, F. 1995. Changes in physical, chemical and physico-chemical parameters during the composting of municipal solid wastes in two plants in Valencia. Bioresource Technology, vol. 51, no 7, 259-264p.

5. Cayuela, M. L., Monedero, M. A. S., \& Roig, A., 2006. Evaluation of two different aeration systems for composting two-phase olive mill wastes. Process Biochemistry, vol. 41, no 6, 616-623p.

6. Cofie, O. O., Agbottah, S., Strauss, M. H., Esseku, Montangero, A., Awuah, E., \& Koné, D. 2006. Solid-liquid separation of faecal sludge using drying beds in Ghana: implications for nutrient recycling in urban agriculture. Water Resources, vol. 40, no. 1, pp. 75-82.

7. Cooper, R. C., \& Golueke, C. G. 1977. Public Health Aspects of OnSite Waste Treatment. Compost Science, vol., 18, no 3, 8-11p.

8. Damien, A. 2004. Guide du traitement des déchets, 3ème édition. Paris, France: 431p.

9. Darimani, S. H., Ito, R., Maiga, Y., Sou, M., Funamizu, N., \& Maig, A. H. 2016. Effect of post-treatment conditions on the inactivation of helminth eggs (Ascaris suum) after the composting process. Environmental Technology vol. 37, no 8.

10. Diabagaté, S. 2009. Analyse de la situation de l'assainissement dans les quartiers défavorisés d'Abidjan; Cas du quartier Sagbé dans la commune d'Abobo; Université d'Abidjan Cocody DEA de Géographie option Environnement; 32 p.

11. Epstein, E., \& Epstein, J.I. 1989. Public health issues and composting. Biocycle. vol. 30, no 8, 50-53p. 
12. Feachem, R. G., Bradley, D. J., Garelick, H., \& Mara, D. D. 1983. Sanitation and Disease: Health Aspects of Wastewater and Excreta Management. World Bank studies in water supply and sanitation, New York: John Wiley and Sons, vol. 3.

13. Forster, J. C., Zech, W., \& Würdinger, E. 1993. Comparison of chemical and microbial methods for the characterization of the maturity of composts from contrasting sources. Biology and Fertilility of. Soils, vol. 16, no 5, 93-99p.

14. Franceys, R., Pickford, J., \& Reed, R. 1995. Guide de l'assainissement individuel. Organisation mondiale de la santé (OMS), Genève, pp.258.

15. Francou, C. 2003. Stabilisation de la matière organique au cours du compostage de déchets urbains: Influence de la nature des déchets et du procédé de compostage recherche d'indicateurs pertinents. Thèse de Doctorat, Institut national agronomique Paris- Grigon, 289p.

16. Haruta, S., Nakayama, T., Nakamura, K., Hemmi, H., Ishii, Igarashi, Y., \& Nishino, T. 2005. Microbial diversity in biodegradation and reutilization processes of garbage. Journal of Bioscience and Bioengineering, vol. 99, no 6, 1-11p.

17. INS. 2001. Recensement Général de la Population et de l'Habitat (RGPH); Données sociodémographiques et économiques des localités, résultats définis par localités, région des lagunes, Abidjan, Côte d'Ivoire, vol. 3, tome 1, 43 p.

18. Jimenez, E. I., \& Garcia, V. P. 1991. Composting of Domestic Refuse and Sewage-Sludge, Capacity. Resources Conservation and Recycling, vol. 6, no 2, 45-60p.

19. John. 2002. Survival, transport, and sources of fecal bacteria in streams and survival in land-applied poultry litter in the Upper Shoal Creek Basin, Southwestern Missouri.

20. Kouassi, F. K. 2008. Impacts du système de réseau d'égout à faible diamètre sur la ressource en eau: le cas du réseau d'Abobo-Sagbé un quartier précaire de la ville d'Abidjan (Côte d'Ivoire), Master spécialisé; $33 \mathrm{P}$.

21. Laos, F., Mazzarino, M. J., Walter, I., Roselli, L., Satti, P., \& Moyano, S. 2002. Composting of fish offal and biosolids in northwestern Patagonia. Bioresource Technology, vol. 81, no 3, 179186.

22. Leclerc, P. 1997. Caractérisation microbiologique des composts à base de résidus chitineux. Canada, p 9-18.

23. Magri, M. E., Philippi, L. S., \& Vinneras, B. 2013. Inactivation of Pathogens in Feces by Desiccation and Urea Treatment for 
Application in Urine-Diverting Dry Toilets. Applied and Environmental Microbilogy, vol. 18, pp. 18.

24. Millner, P. D., Marsh, R. B., Snowden, \& Parr, J. F. 1977. Occurrence of Aspergillus fumigatus During Composting of Sewage Sludge. Applied and Environmental Microbiology, vol. 34, no 6, 765-772p.

25. Mustin, M. 1987. Le Compost, Gestion de la Matière Organique, F. Dubusc eds, Paris, 957p.

26. Nakagawa, N., Oe, H., Otaki, M., \& Ishizaki, K. 2006. Application of microbial risk assessment on a residentially-operated Bio-toilet. Journal of Water and Health, vol. 4, pp. 479-486.

27. NF T 90-006. 1950. pH Essais des eaux - Mesure colorimétrique du $\mathrm{pH}$, code $13,1950$.

28. NF EN ISO 9308-1. 2000. Qualité de l'eau - Recherche et dénombrement des Escherichia coli et des bactéries coliformes Partie: méthode par filtration sur membrane.

29. Nsavyimana, G. 2014. Modelisation des processus physiques et biologiques dans des fosses septiques et voies de valorisation des boues de vidange: application à bujumbura-burundi. Thèse de doctorat en sciences et gestion de l'environnement, Université de Liège, Liège, Belgique, 427p.

30. Ogunyoku, T. A., Habebo, F., \& Kara, L. N. 2016. In-toilet disinfection of fresh fecal sludge with ammonia naturally present in excreta. Journal of Water Sanitation and Hygiene for Development, vol. 6, no. 1, pp. 104-114.

31. ONU-Habitat. 2012. Côte d'Ivoire; Profil urbain d'Abobo. Nairobi, Editions UNON; $32 \mathrm{p}$.

32. Otaki, M., Nakagawa, N., Kazama, S., Akaishi F., \& Tameike, N. 2007. Hygenic risk assessment and control in using composting toilet, Proceedings of the 7th International Symposium on Sustainable Sanitation, pp 91-98.

33. Pambrun, V. 2005. Analyse et modélisation de la nitrification partielle et de la précipitation concomitante du phosphore dans un réacteur à alimentation séquencée. Ph.D. Thesis, Genie des Procédés et de l'Environnement, Institut National des Sciences Appliquées de Toulouse, 287p.

34. Pederson, D. C. 1983. Effectiveness of sludge treatment processes in reducing levels of bacteria, viruses and parasites, In P. M. Wallis and D. L. Lehman (ed.), Biological health risks of sludge disposal to land in cold climates. University of Calgary Press, Calgary, Alberta, Canada, p. 9-31. 
35. Pereira N. J.T., Stentiford E.I., \& Mara D.D. 1987. Comparative survival of pathogenic indicators in windrow and static pile. Compost: Production. Quality and Use. Éditeur: Elsevier Science Publishing Co, USA, 276-295 pp.

36. Qdais, H. A., \& Al-Widyan, M. 2016. Evaluating composting and cocomposting kinetics of various agro-industrial wastes. Int J Recycl Org Waste Agricult, 5, 273-280.

37. Qian, Z., Xia H., \& Yan, T. 2015. Differential decay of wastewater bacteria and change of microbial communities in beach sand and seawater microcosms. Environmental Science and Technology, vol. 49, no $14,8531-8540$.

38. Team, R. C. 2016. R: A language and environment for statistical computing. R Foundation for Statistical Computing, Vienna. URL https://www.R-project.org/

39. Remy, A. 2007. Co-compostage de boues de station d'épuration et de déchets verts: Nouvelle méthodologie du suivi des transformations de la matière organique. Thèse de doctorat, Sciences de la Terre. Université de droit, d'économie et des sciences - Aix-Marseille III, France.

40. Reveille, V., Mansuy, L., Jarde, E., \& Garnier-Sillam, E. 2003. Characterisation of sewage sludge-derived organic matter: lipids and humic acids. Organic Geochemistry, vol. 34, no 2, 615-627p.

41. RGPH. 2014. Quatrième recensement général de la population et de l'habitat. Résultats globaux par Sous-Préfecture ou commune (Côte d'Ivoire), p. 2 .

42. Sghairoun, M., \& Ferchichi, A. 2011. Composting Heap Palm Tree's Products in Southern Tunisia. Journal of Environmental Science and Engineering, vol. 5, no 2, 886-889p.

43. Sossou, S. K., Dakoure, M. S., Konate, Y., Maiga, A. H., \& Funamizu, N. 2016. Inactivation kinetics of indicator microorganisms during urea treatment for sanitizing finished compost from composting toilet. Journal of Water, Sanitation and Hygiene for Development vol. 6, no 2.

44. Sossou, S. K. 2016. The fate of intestinal parasites and pathogenic bacteria in the composting toilet, thesis of Doctor of Philosophy in Engineering, Faculty of Engineering, Hokkaido University, Japan, 96p.

45. Strom, P.F., \& Finstein, M.S. 1989. Leaf composting manual for New Jersey municipalities. Department of Environmental Science, Cook College and the N.J. Agricultural Experiment Station, New Jersey. 29p. 
46. Sundberg, C., Smars, S., \& Jonsson, H. 2004. Low pH as an inhibiting factor in the transition from mesophilic to thermophilic phase in composting. Bioresource Technology, vol. 95, no 3, 145$150 \mathrm{p}$.

47. Tang, J. C., Kanamori, T., Inoue, Y., Yasuta, T., Yoshida, S., Katayama, A. 2004. Changes in the microbial community structure during thermophilic composting of manure as detected by the quinone profile method. Process Biochemistry, vol. 39, no 3, 19992006p.

48. US EPA. 2009. Pathogen Equivalency Committee (PEC): Basic Information

49. Yang, J., \& Scholten, T. A. 1977. Fixative for intestinal parasites permitting the use of concentration and permanent staining procedures. Am. J. Clin. Pathol. vol. 67 no 3, 300-304.

50. Znaïdi, I. 2002. Etude et évaluation du compostage de différents types de matières organiques et des effets des jus de composts biologiques sur les maladies des plantes. Master of science degree mediterranien organic agriculture, Mediterranien Agronomic Institute of Bari, Tunisie, 104p. 